\title{
Research Paper Evolution of mechanization index and used pattern for mini tractor and its equipments in Junagadh district
}

See end of the paper for authors' affiliations

Correspondence to :

\section{Nikunjkumar D.}

Vadhiya

Post Graduate Institute of Agri-Business

Management, Junagadh Agricultural University, Junagadh (Gujarat) India

\section{Paper History :}

Received : 25.06.2018;

Revised : 04.09.2018;

Accepted : 10.09 .2018
ABSTRACT : The present study evolution of mechanization index and used pattern for mini tractor and its equipments in Junagadh district during the year 2018. The study was revealed that 90 per cent farmers were use M.B. plough while 10 per cent farmers not use M.B. plough. Whole 100 per cent farmers were using rotavetor, cultivator, intercultural operation and transport. No farmers were use thresher and irrigation system by tractor. It was found that most of farmer use rotavator and M.B. plough in hire basis for intercultural operation, transport and cultivator operation farmers use own implements. It was found that M.B. plough and rotavator hiring rates is higher than the other operations i.e. cultivator, intercultural operation and transport. It was found that M.B. plough, cultivator and rotavator highest observed in 21 to 40 hours annual use. For intercultural operation and transport highest observed 41 to 60 hours use category. In Junagadh district no farmers use irrigation pump and thresher by using mini tractor. It was found that irrigation mechanization index is the highest mechanization index in district it found 88.33 per cent. Intercultural mechanization index is the second highest mechanization of district as it found 74.64 per cent, followed by sowing and spraying mechanization index. According to the study lowest mechanization index was found of fertilizer application and threshing operations.

KEY WORDS : Mini tractor use pattern, Mechanization index

HOW TO CITE THIS PAPER : Vadhiya, Nikunjkumar D., Thaker, Nisha M. and Bhatt, Jagruti D. (2018). Evolution of mechanization index and used pattern for mini tractor and its equipments in Junagadh district. Res.J. Agric. Eco. \& Stat., 9 (2) : 393-398, DOI : 10.15740/HAS/IRJAES/9.2/393-398. Copyright@ 2018: Hind AgriHorticultural Society. 